\title{
PREPARATION OF SECON DARY PH OF PHTHALATE BUFFER SOLUTION USING DIFFERENTIAL POTENTIOMETRIC CELL: METHOD VALIDATION AND APPLICATION
}

\author{
Ayu Hindayani ${ }^{1}$, Oman Zuas $^{1, *}{ }^{*}$, Sujarwo ${ }^{2}$, Fransiska S. H. Krismastuti ${ }^{2}$, Nuryatini ${ }^{1}$
}

https://doi.org/10.23939/chcht13.03.377

\begin{abstract}
A secondary $\mathrm{pH}$ of phthalate buffer was prepared by differential potentiometry method using a Baucke cell which is separated by sintered glass disk in the middle of cell - so called two-half cells. The method has been validated at $298 \mathrm{~K}$ with the purpose to evaluate its suitability for meeting the application requirement. The method validation parameters include accuracy (bias), precision (repeatability), and estimation of measurement uncertainty. It was found that both accuracy and precision of the method were good, which is indicated by their very low standard deviation (SD). The measurement uncertainty value of the method was estimated. Application of the validated analytical method for the measurement of phthalate buffer in an international comparative test (APMP.QM-K91) showed that the result was close to the APMP.QM-K91's Key Comparison Reference Value.
\end{abstract}

Keywords: differential potentiometric cell, $\mathrm{pH}$, phthalate buffer, method validation, international key comparison.

\section{Introduction}

Scientifically, $\mathrm{pH}$ is defined as a value of $-\log a_{H}$, involving a single ion quantity and activity of hydrogen ion [1]. Practically, the $\mathrm{pH}$ is used to specify acidity or basicity properties of any substance that are mainly in the form of their aqueous solution. Determination of $\mathrm{pH}$ is one of the most common and frequent quantitative measurement in the field of chemical analyzes [2]. The

\footnotetext{
${ }^{1}$ Metrology in Chemistry Laboratory, Centre for Research and Human Resource Development,

National Standardization Agency of Indonesia (BSN),

Kawasan PUSPIPTEK Build. 420, Serpong15314, Tangerang

Selatan-Banten, Indonesia

${ }^{2}$ Research Centre for Chemistry-Indonesian Institute of Sciences (RCChem-LIPI)

Kawasan PUSPIPTEK Build. 452, Serpong15314, Tangerang

Selatan-Banten, Indonesia

*oman@bsn.go.id; zuas.oman@gmail.com

(C) Hindayani A., Zuas O., Sujarwo, Krismastuti F., Nuryatini, 2019
}

common application of the $\mathrm{pH}$ measurement is to control industrial processes with the purposes to preserve product quality, reduce the corrosion rate in plant equipment, and protect the aqueous environment by helping wastewater discharge process to meet regulatory limits [3].

Measurement of $\mathrm{pH}$ is a process applying the physico-chemical principle and it can be performed by using various methods such as colorimetry and potentiometry. To date, potentiometry is widely used due to its simplicity and accuracy in comparison to other methods [4]. Potentiometric method is measuring the potential difference between two electrodes that are simultaneously immersed in the solution to be examined [5], by which those glass electrodes must be regularly calibrated before use by using $\mathrm{pH}$ buffer standard solution.

A reliable data of a $\mathrm{pH}$ measurement process having a traceability property to the International System of Units (SI) is extremely required [2]. For $\mathrm{pH}$ measurement, the traceability chain can be established by linking the $\mathrm{pH}$ data resulted from a measurement to the $\mathrm{pH}$ value of a primary $\mathrm{pH}$ buffer standard solution [6]. This buffer standard is obtained from the primary method [2]. It is widely known that the primary $\mathrm{pH}$ buffer standard solution for the calibration purpose is characterized by its long-term stability, high purity and good reproducibility [6]. However, the use of primary $\mathrm{pH}$ buffer standard solution by common testing and calibration laboratories is costly; thus secondary $\mathrm{pH}$ buffer standard solution is an alternative which is widely used by the laboratories to keep the traceability of their $\mathrm{pH}$ measured data [2].

So far, the $\mathrm{pH}$ value of secondary $\mathrm{pH}$ standard buffer solution is commonly determined by secondary method using differential potentiometric cell or called as Baucke cell. This method was firstly introduced in 1994 by F. Baucke, whose name was then used for naming the cell [2]. Schematic design of Baucke cell is presented in Fig. 1 [6]. 


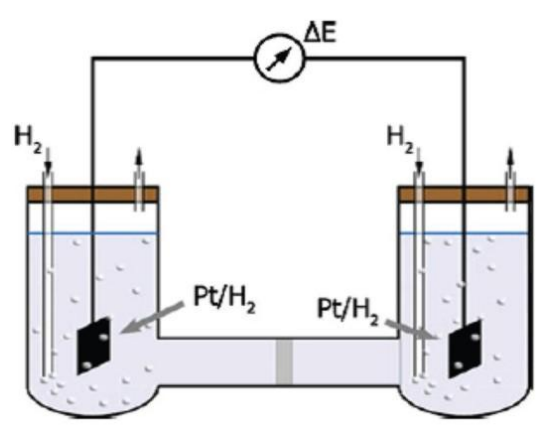

Fig. 1. Schematic diagram of Baucke cell [6]

Baucke cell is U-shaped cell separated by a sintered glass disk in the middle of the cells, called as two-half cells. One cell contains the primary buffer solution (as a standard solution) and platinum/hydrogen $\left(\mathrm{Pt} / \mathrm{H}_{2}\right)$ electrode. Another cell contains secondary buffer solution (as a sample solution) and $\mathrm{Pt} / \mathrm{H}_{2}$ electrode. These two buffer solutions must have the same nominal composition. Similarly, two $\mathrm{Pt} / \mathrm{H}_{2}$ electrodes must have as similar characteristic as possible. Since the hydrogen in the half cells is about the same, liquid junction potential (LJP, developed in the junction between the two half cells) can be neglected [2]. The $\mathrm{pH}$ of secondary buffer can be calculated by Eq. (1) [2]:

$$
\mathrm{pH}_{s}=\mathrm{pH}_{p}-\frac{\Delta E_{\text {cell }} F}{R T \ln 10}
$$

where $\mathrm{pH}_{p}$ is $\mathrm{pH}$ value from primary buffer standard solution; $\Delta E_{\text {cell }}$ is potential difference between two $\mathrm{Pt} / \mathrm{H}_{2}$ electrodes after stabilization $(\mathrm{V}) ; F$ is Faraday constant $\left(96,485 \mathrm{C} \cdot \mathrm{mol}^{-1}\right), \quad R$ is the universal gas constant $\left(8.314 \mathrm{~J} \cdot \mathrm{K}^{-1} \cdot \mathrm{mol}^{-1}\right) ; T$ is solution temperature (K) [2].

In Indonesia, most of industrial and testing laboratories used imported and traceable buffer standard solutions in their $\mathrm{pH}$ measurement activities [7]. The use of traceable secondary $\mathrm{pH}$ buffer standard solutions is extremely important to keep the traceability of the measurement to the SI unit. However, an imported buffer standard solution is economically disadvantageous due to being costly and the import process is also time consuming. Therefore, providing the industries and testing laboratories with secondary buffer standard solution to meet the local need is essential.

In $\mathrm{pH}$ measurement, the phthalate buffer is one of the most commonly used in comparison to other buffer standard solutions because it is readily commercial available, relatively stable and $\mathrm{pH}$ value is markedly nonsensitive to a temperature change [8]. In addition, the phthalate buffer standard solution can be easily prepared from readily available certified material.

In this study, a phthalate buffer solution as a secondary $\mathrm{pH}$ buffer standard solution was developed by
LIPI. The secondary $\mathrm{pH}$ buffer standard solution was prepared by using gravimetric method and the $\mathrm{pH}$ values were determined by the differential potentiometry method using a Standard Reference Material ${ }^{\circledR}$ potassium hydrogen phthalate $\left(\mathrm{SRM}^{\circledR} 185 \mathrm{i}\right)$ as the traceable reference standard. It is important to notice that methods for the preparation and $\mathrm{pH}$ measurement must be validated before determining the $\mathrm{pH}$ value and producing the phthlate buffer solution in a large scale. The purpose of the method validation is not only to meet its suitability requirement for application but also to evaluate the method's performance [9], by which the results are presented and discussed in this paper.

\section{Experimental}

\section{1. $M$ aterials}

All chemicals were of analytical grade, otherwise stated, and used as received without any further purification. Hydrogen $\left(\mathrm{H}_{2}\right)$ gas $(99.9 \%$ purity) was purchased from SII Gas Indonesia. Chloride acid (37\% purity), nitric acid (65\% purity), lead (II) acetate (99.5\% purity), Certipure ${ }^{\circledR}$ Certified Reference Material (CRM) potassium hydrogen phthalate (1019650025) were purchased from Merck, Germany. Palladium (II) chloride (anhydrous, Pd basis $60 \%$ ) was purchased from SigmaAldrich, USA. The SRM $^{\circledR} 185 i$ was purchased from National Institute of Standards and Technology (NIST), USA. Demineralized water $(0.05 \mu \mathrm{s} / \mathrm{cm})$ was produced from a Thermo Scientific Barnsted Smart2 pure water purification system and used in all experiments.

\subsection{Equipment}

For the investigations we used: analytical balance with accuracy of $1 \mathrm{mg}$ (PR5003 Dual Range, Mettler Toledo Switzerland), oven (Heraeus Instruments, Germany) and a direct current (DC) power supply 0.01 A (Ad-8723D, China), a digital multimeter $0.01 \mathrm{mV}$ (34461A, Agilent Technologies Sdn Bhd, Malaysia), waterbath $0.1 \mathrm{~K}$ (Thomas T-N22D, Japan), chiller (Thomas TRL-117NF, Japan), hot plate and magnetic stirer (Cimarec 2, Barnstead Thermolyne Corp. USA), fume hood (LFH-2120V, Daihan Labtech Korea), digital thermometer (MKT50, Anton Paar GmBH, Germany), Baucke Cell, Pt electrode, and chamber (Japan), stopwatch, and clean glasswares.

\subsection{Procedure}

\subsubsection{Preparation of buffer solution}

Standard buffer solution was made from phthalate buffer solution $(0.05$ molal $) \mathrm{SRM}^{\circledR} 185$ i by adopting a 
procedure from [10]. In a typical experiment, the SRM $^{\circledR}$ NIST $185 \mathrm{i}$ was firstly dried at $383.15 \mathrm{~K}$ for $2 \mathrm{~h}$ followed by storing in a desiccator until use, aiming to remove the water content because the $\mathrm{SRM}^{\circledR} 185 \mathrm{i}$ is stable only in a dry environment. After that, $9.8 \mathrm{~g}$ of SRM $185 \mathrm{i}$ was transferred into a clean and dry beaker glass (1 1 ). Demineralized water was then added into the beaker glass until the mass reach $959.293 \mathrm{~g}$. The solution was shaken thoroughly until the solid was totally dissolved. This gravimetric preparation could eliminate the need to weigh exactly predetermined mass of solid samples.

Another buffer solution ( 0.05 molal), as a sample, was made from Certipure ${ }^{\circledR}$ CRM potassium hydrogen phthalate in accordance with the procedure described in [11]. The CRM was dried by placing in an oven at $383.15 \mathrm{~K}$ for $2 \mathrm{~h}$ in order to remove the water content. After that, $10.21 \mathrm{~g}$ of CRM was dissolved in $800 \mathrm{ml}$ of water and made up to $1 \mathrm{l}$. The solution was shaken thoroughly until the solid was totally dissolved.

\subsubsection{Preparation of Pt electrode}

The use of clean Pt electrodes in $\mathrm{pH}$ measurements by differential potentiometric cell is considered very important. In this study, the Pt electrodes were cleaned using hot aqua regia in order to achieve a sufficiently small of potential bias [12] and to remove any impurities from the electrode surface, by which the possible interference during the measurement can be diminished [13]. After that, a palladinizing process for the $\mathrm{Pt}$ electrode to minimize reduction of phthalate was carried out by coating method using palladium black solution [8]. Typically, palladium black solution was a solution mixture consisting of palladium chloride, lead acetate and chloride acid, where the Pt electrodes were coated by electrolytic method [12]. The presence of the palladium black on the electrode surface may increase the effectiveness of a hydrogen electrode [14]. Preliminary results showed that a slightly coated electrode surface was found to be more stable than thick coated one [8]. To determine the best surface coating of the electrodes, the effect of palladinizing parameters such as current and time were studied. The variation of the current and time was ranging within $0.3-0.5 \mathrm{~A}$ and 2-5 min, respectively.

\subsection{3. pH Measurements}

The $\mathrm{pH}$ of phthalate buffer 0.05 molal (both standard and sample) were measured by using differential potentiometric cell. The potential difference between $\mathrm{SRM}^{\circledR} 185 \mathrm{i}$ as a standard and Certipure ${ }^{\circledR} \mathrm{CRM}$ potassium hydrogen phthalate as a sample was assigned as $\Delta E_{\text {cell }}$. Both buffer solutions were placed in the Baucke cell, followed by inserting the palladinized Pt electrodes into each cell. After that, the Baucke cell was immersed into the waterbath $(298 \mathrm{~K})$. The hydrogen gas was then fed into each cell with the flow rate of $500 \mathrm{ml} / \mathrm{h} \mathrm{[12].} \mathrm{It} \mathrm{should}$ be noticed that the hydrogen gas was firstly prehumidified before entering the Baucke cell by passing through the hydrogen into two chambers containing phthalate buffer solution [2]. The palladinized $\mathrm{Pt}$ electrodes were then connected to digital multimeter and the $\Delta E_{\text {cell }}$ value was recorded after stabilization. A schematic diagram of the differential potentiometric cell system used in this study is shown in Fig. 2. In this study, one hour was required to stabilize the potential and the measurement was then conducted every $10 \mathrm{~min}$. Finally, the mean value of $\Delta E_{\text {cell }}$ was used for calculating the $\mathrm{pH}$ values by using Eq. (1).

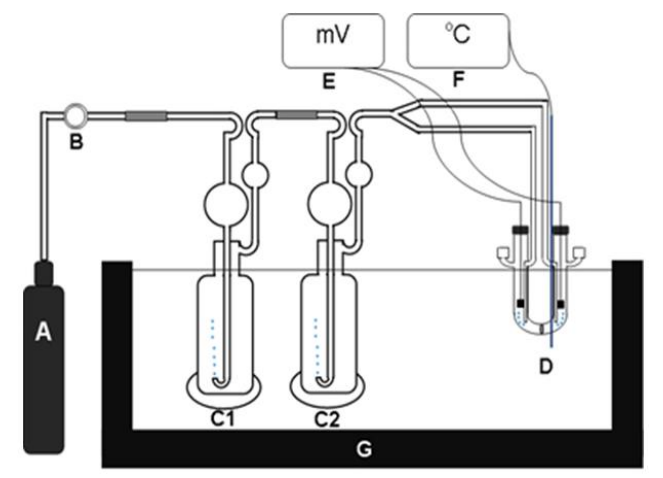

Fig. 2. Schematic diagram of differential potentiometric cell system: hydrogen gas (A), gas controller (B), chambers containing phthalate buffer (C1 and C2), Baucke cell and $\mathrm{Pt}$ electrodes (D), digital multimeter (E), digital thermometer (F) and water bath (G)

\subsubsection{Validation method}

Validation of an analytical method is a process of defining an analytical requirement and confirming that the method under consideration has capabilities and is consistent with its application requirements [9]. In this study, differential potentiometric cell was used for the preparation of secondary reference material for $\mathrm{pH}$ measurement; thus, validation of the method is extremely required to meet its application purposes. In general, validations of the method are conducted to evaluate the performance characteristics of the method in term of its selectivity, limit of detection (LOD) and limit quantification (LOQ), working range, analytical sensitivity, accuracy (bias), precision (repeatability), robutsness, and estimation of measurement uncertainty [9]. However, in analytical $\mathrm{pH}$ measurement, the validation method is only limited to such parameters as accuracy (bias), precision (repeatability) and measurement of the uncertainty.

Accuracy is referred to how close the mean of measurement result (produced by method) is to the 
reference value. This assessment is commonly quantitatively expressed as bias [9]. Determination of bias (b) relies on the different between the mean of measurement results $(\bar{X})$ and the reference value stated in CRM's certificate $\left(X_{C R M}\right)$. The value of $b$ is determined by using Eq. (2) [9].

$$
b=\left|\bar{X}-X_{C R M}\right|
$$

In this study, the mean from 10 times of measurements was used. The method is categorized as not to be bias, when the value falls within the range of measurement precision value $( \pm 2 \sigma)$ (Eq. (3)) with calculation of $\sigma$ (Eq. (4)) at 95\% confidence level [15].

$$
\sigma=\sqrt{U_{C R M}^{2}+\frac{S_{w}^{2}}{n}}
$$

where $U_{C R M}$ is standard uncertainty from certificate; $S_{w}$ is standard deviation, and $n$ is a number of measurements.

Precision (also called as repeatability) is a measure of how close the measurement results are one to another [9]. Precision is usually expressed by a standard deviation obtained from several measurement replications. In the $\mathrm{pH}$ measurement using differential potentiometric cell, a good repeatability is achieved when the value of standard deviation is equal or less than $6.0 \cdot 10^{-5} \mathrm{~V}$. This criterion is based on our experiences in the measurement using differential potentiometric cell to decrease the measurement uncertainty.

Moreover, for estimating the uncertainty of the measurement, identification of the uncertainty sources which contribute to the measurement uncertainty value is the initial step. After that, estimation of the uncertainty from each individual source was conducted followed by combining such individual uncertainties to give an overall estimation of measurement uncertainty [16].

\section{Results and Discussion}

In the BSN, the electrochemistry laboratory is a part of metrology in chemistry group which has responsibility for the development of reference material in electrochemistry field such as buffer. The developed buffer reference materials are used to keep the traceability of $\mathrm{pH}$ measurement (at national level) to SI. It might be an acceptable idea that every method must be validated before coming into use for a routine measurement. In this study, the measurement of the phthalate buffer was determined by secondary method using differential potentiometric cell and the method was validated in term of the measurement accuracy (bias), precision (repeatability), and its measurement uncertainty estimation.

\subsection{Palladinizing Pt Electrodes}

Optimization of palladinizing Pt electrode is an important step and it has to be conducted to increase the work efficiency of the $\mathrm{Pt}$ electrode, because in homogeneities such as tiny spots on the electrode surface may affect the measurement results. Therefore, any surface dirt must be removed by cleaning procedure [12]. Besides, in the differential potentiometry, the surface condition of two Pt electrodes must be as similar as possible [2].

Fig. 3 shows the $\Delta E_{\text {cell }}$ dependency on the electrical current used in the palladinizing Pt electrode. It can be seen from Fig. 3 that the obtained $\Delta E_{\text {cell }}$ value significantly decreases when the electrical current increases up to $0.4 \mathrm{~A}$ and then increases. This phenomenon can be described as follows: at a low current (below $0.4 \mathrm{~A}$ ) in palladinizing, only a small number of metal was deposited on the surface of Pt electrode and that was a non-optimum condition to minimize the reduction process of phthalates, leading to a very large $\Delta E_{\text {cell }}$ value. In contrast, at a high current (above $0.4 \mathrm{~A}$ ), the $\Delta E_{\text {cell }}$ value is significantly increased. These high $\Delta E_{\text {cell }}$ values might be due to the high current used in the palladinizing resulting in inhomogeneity of deposited metal on the electrode surface [17]. Consequently, two Pt electrodes were unidentical and those electrodes did not meet the requirement of the electrodes used in potential differential potentiometric cell. Moreover, when palladinizing at the current of $0.4 \mathrm{~A}$, the $\Delta E_{\text {cell }}$ was found to be the smallest value, indicating that two half cells were similar, having homogenous deposition of metal on the electrode surface. Based on this finding, a value of $0.4 \mathrm{~A}$ was used as the optimal current in palladinizing the Pt electrodes.

Fig. 4 displays the effect of time variation on the $\Delta E_{\text {cell }}$ value. As it can be seen from Fig. $4, \Delta E_{\text {cell }}$ decreases in 2-4 min and then increases in $5 \mathrm{~min}$. For $2 \mathrm{~min}$, the $\Delta E_{\text {cell }}$ was found to have a relatively high value. It was assumed that due to the short time of palladinizing process a very small amount of metal is deposited on the electrode surface (data are not shown here). Thus, the reduction of phthalates cannot be minimized. On the contrary, longer palladinizing time may decrease the $\Delta E_{\text {cell }}$ value and the lowest value of $\Delta E_{\text {cell }}$ is achieved in 4 min, indicating that the metal deposited on the electrode surface was in a homogenous and optimum condition. Consequently, the smallest $\Delta E_{\text {cell }}$ value confirms that the optimum palladinizing time is $4 \mathrm{~min}$.

So, it can be concluded that the optimum electrical current and reaction time were $0.4 \mathrm{~A}$ and $4 \mathrm{~min}$, respectively. The $\mathrm{Pt}$ electrode obtained under this optimum condition was then used for the measurements in the validation of the analytical method. 


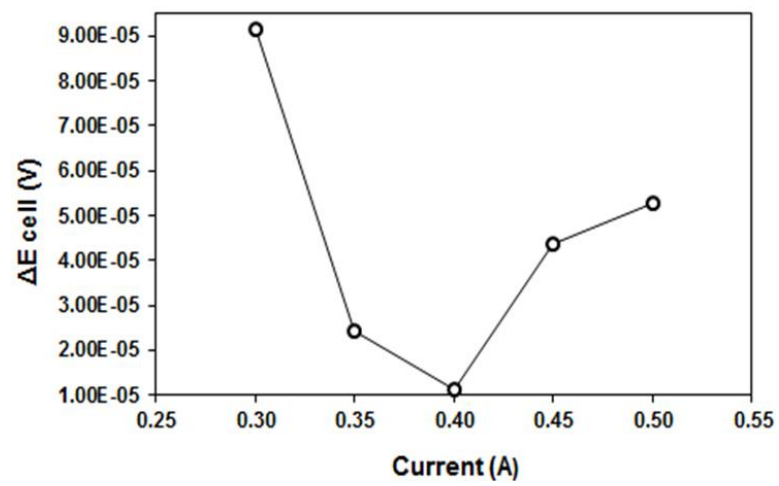

Fig.3. The dependence of $\Delta E_{\text {cell }}$ on the electrical current in Pt electrodes palladinizing

\subsection{Validation Method}

In this study, the validation of the measurement method was conducted in terms of accuracy (bias), precision (repeatability) and measurement uncertainty estimation. For the accuracy, the evaluation was taken by estimating the bias of the mean true value from 10 measurement replications. The results of the method accuracy are presented in Table 1 . It can be seen from Table 1 that the mean of $\mathrm{pH}$ value of the CRM was found to be 4.0052 , while the certificate value of the secondary phthalate buffer was 4.0070; thus the bias of the method was 0.0018 . This bias value is relatively small and lies in the range of the precision value $\pm 2 \sigma$ (with $95 \%$ confidence level), implying that the analytical method is accurate [15].

Table 1

Accuracy data of the analytical method

\begin{tabular}{|c|c|}
\hline Measurements & $\mathrm{pH}$ at $298 \mathrm{~K}$ \\
\hline 1 & 4.0045 \\
\hline 2 & 4.0051 \\
\hline 3 & 4.0050 \\
\hline 4 & 4.0056 \\
\hline 5 & 4.0057 \\
\hline 6 & 4.0057 \\
\hline 7 & 4.0053 \\
\hline 9 & 4.0056 \\
\hline 10 & 4.0050 \\
\hline Mean $(\bar{X})$ & 4.0049 \\
\hline Standard deviation $\left(S_{w}\right)$ & 4.0052 \\
\hline$U_{C R M}$ & 0.0004 \\
\hline$X_{C R M}$ & 0.0015 \\
\hline$b=\left|\bar{X}-X_{C R M}\right|($ Eq. 2$)$ & 4.0070 \\
\hline$\sigma=\sqrt{U_{C R M}^{2}+\frac{S_{w}^{2}}{n}(\text { Eq. } 4)}$ & 0.0018 \\
\hline Criteria $-2 \sigma<<($ Eq. 3) & $-0.0030<0.0018<0.0030$ \\
\hline Status & 0.0015 \\
\hline
\end{tabular}

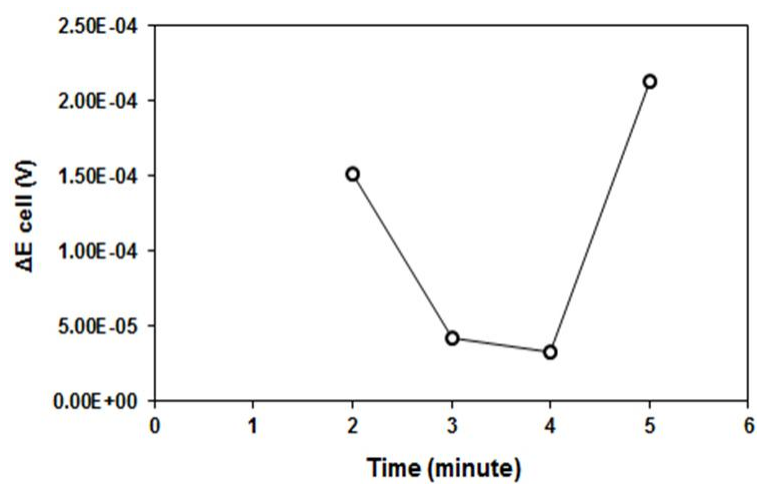

Fig. 4. Optimization of time in Pt electrodes palladinizing

Precision (repeatability) is a measure of how close the measurement results are to each other [9]. The precision is usually expressed by standard deviation from several measurement replications. In this study, repeatability was carried out by measure of the sample in 10 replications and the results are listed in Table 2. From the Table 2, it was found that the standard deviation for the measurement is $3.0 \cdot 10^{-5}$ which is lower than acceptance criteria value $\left(6.0 \cdot 10^{-5} \mathrm{~V}\right)$ of our experience in measurement using differential potentiometric cell. Hence, it can be concluded that the analytical method used in this study is precise (repeatable). Moreover, for the measurement uncertainty estimation, all possible sources of the uncertainty contributor were identified and schematically displayed using Ishikawa diagram as shown in Fig. 5 [2].

Table 2

\section{Precision/repeatability data of the analytical method}

\begin{tabular}{|c|c|}
\hline Measurements & $\Delta E_{\text {cell }}$ at $298 \mathrm{~K}, \mathrm{~V}$ \\
\hline 1 & 0.00009 \\
\hline 2 & 0.00001 \\
\hline 3 & 0.00005 \\
\hline 4 & 0.00004 \\
\hline 5 & 0.00002 \\
\hline 6 & 0.00005 \\
\hline 7 & 0.00008 \\
\hline 8 & 0.00008 \\
\hline 9 & 0.00001 \\
\hline 10 & 0.00008 \\
\hline Mean $(\bar{X})$ & 0.00005 \\
\hline Standard deviation $\left(S_{w}\right)$ & $3.0 \cdot 10^{-5}$ \\
\hline Criteria & equal or less than $6.0 \cdot 10^{-5}$ \\
\hline Status & OK \\
\hline
\end{tabular}

Table 3 shows the measurement uncertainty estimation for secondary $\mathrm{pH}$ measurement. From Table 3, it can be seen that the expanded uncertainty for the secondary $\mathrm{pH}$ measurement using differential potentio- 
metric cell at $298 \mathrm{~K}$ is 0.001 (95\% confidence level), which is lower than the IUPAC recommended value (0.004 at $95 \%$ confidence level) [1]. Extremely small uncertainty of the primary buffer used might be the reason for small uncertainty obtained in this study, indicating that uncertainty of the primary buffer is very important [2].

\subsection{Application}

Validation method of the secondary $\mathrm{pH}$ measurement using differential potentiometric cell is to check the suitability of the differential potentiometry method with the application required and evaluate the method's performance. In this regard, participation in an international key comparison (APMP.QM-K91) was conducted. In short, the comparison results indicated that differential potentiometric cell can be used in the $\mathrm{pH}$ measurements of phthalate buffer at $298 \mathrm{~K}$. The measured value (4.006) is close to the APMP.QM-K91's key comparison reference value (KCRV), that is 4.00765 . The results are graphically displayed in Fig. 6 [18].

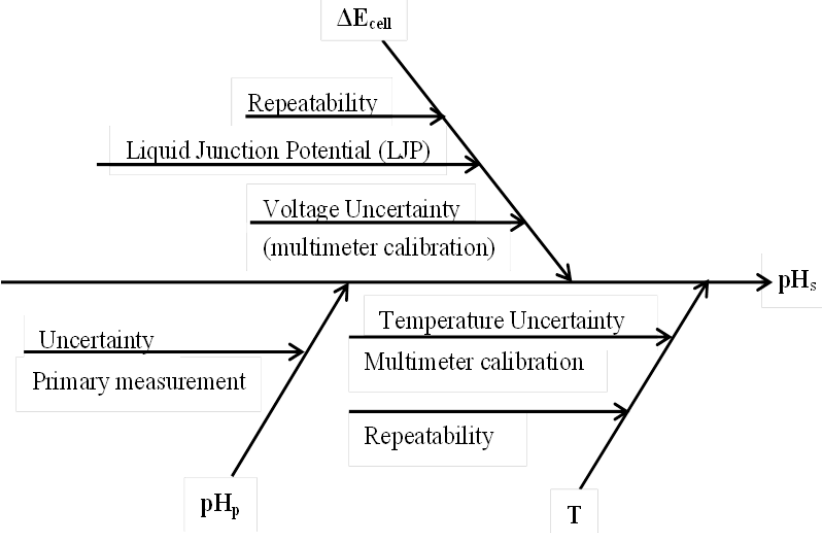

Fig. 5. Ishikawa diagram [2]

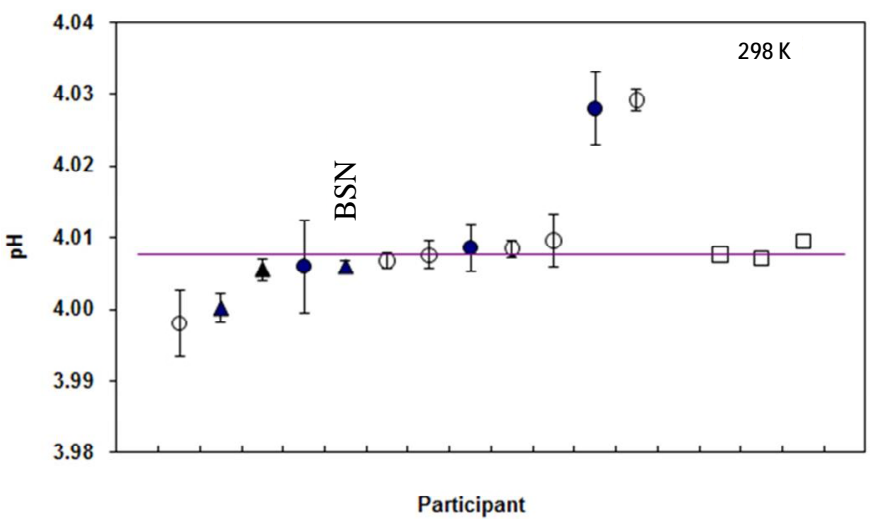

Fig. 6. Results of $\mathrm{pH}$ measurements of phthalate buffer at 298 K compared with APMP.QM-K91 [18]

Table 3

Data for uncertainty estimation of secondary pH measurement using differential potentiometric cell at $298 \mathrm{~K}$

\begin{tabular}{|c|c|c|c|c|c|}
\hline Sources & $\begin{array}{c}\text { Standard } \\
\text { uncertainty }\left(u_{i}\right)\end{array}$ & Unit & $\begin{array}{c}\text { Sensitivity } \\
\text { coefficient }\left(c_{i}\right)\end{array}$ & Unit & $u_{i} \cdot c_{i}$ \\
\hline Primary buffer & 0.0004 & - & 1 & - & 0.0004 \\
\hline \multicolumn{6}{|l|}{$\Delta E_{\text {cell }}$} \\
\hline$E_{\text {cal. }}$ & $5.50 \cdot 10^{-7}$ & $\mathrm{~V}$ & -16.91 & $\mathrm{~V}^{-1}$ & $-9.30 \cdot 10^{-6}$ \\
\hline$E_{\text {res. }}$ & $5.77 \cdot 10^{-7}$ & $\mathrm{~V}$ & -16.91 & $\mathrm{~V}^{-1}$ & $-9.76 \cdot 10^{-6}$ \\
\hline$E_{\text {stab. }}$ & $2.00 \cdot 10^{-5}$ & $\mathrm{~V}$ & -16.91 & $\mathrm{~V}^{-1}$ & $-3.38 \cdot 10^{-4}$ \\
\hline Repeatability & $3.23 \cdot 10^{-6}$ & $\mathrm{~V}$ & -16.91 & $\mathrm{~V}^{-1}$ & $-5.46 \cdot 10^{-5}$ \\
\hline LJP & $3.53 \cdot 10^{-6}$ & $\mathrm{~V}$ & -16.91 & $\mathrm{~V}^{-1}$ & $-5.96 \cdot 10^{-5}$ \\
\hline \multicolumn{6}{|l|}{ Temperature } \\
\hline$T_{\text {cal. }}$ & 0.02 & $\mathrm{~K}$ & $2.0 \cdot 10^{-6}$ & $\mathrm{~K}^{-1}$ & $3.0 \cdot 10^{-8}$ \\
\hline$T_{\text {res. }}$ & 0.06 & $\mathrm{~K}$ & $2.0 \cdot 10^{-6}$ & $\mathrm{~K}^{-1}$ & $1.15 \cdot 10^{-7}$ \\
\hline Stability & 0.06 & $\mathrm{~K}$ & $2.0 \cdot 10^{-6}$ & $\mathrm{~K}^{-1}$ & $1.20 \cdot 10^{-7}$ \\
\hline Homogeneity & 0.04 & $\mathrm{~K}$ & $2.0 \cdot 10^{-6}$ & $\mathrm{~K}^{-1}$ & $8.0 \cdot 10^{-8}$ \\
\hline & & & & $\begin{array}{c}\text { Combined uncertainty } \\
\left(u_{c}\right)\end{array}$ & 0.0005 \\
\hline & & & & $\begin{array}{c}\text { Expanded uncertainty } \\
(U), \\
k=2 \\
\end{array}$ & 0.001 \\
\hline
\end{tabular}




\section{Conclusions}

The result of validation shows that the differential potentiometry method is appropriate for the $\mathrm{pH}$ measurement of phthalate buffer at $298 \mathrm{~K}$, with the value of the bias and precision found to be 0.0018 , and $3.0 \cdot 10^{-5}$, respectively, having an estimated uncertainty value of $0.001(k=2)$. The validated method of $\mathrm{pH}$ has been tested by participating in the international comparison (APMP.QM-K91) and the result was excellent, confirming that the method is valid.

\section{Acknowledgments}

The author would like to thank Mrs. Eli Susilawati for the help during laboratory experiments and data collection. The LIPI support of the study through the project "Strengthening chemical metrology competency and infrastructure" is highly acknowledged.

\section{References}

[1] Buck R., Rondinini S. et al.: Pure Appl. Chem. 2002, 74, 2169. https://doi.org/10.1351/pac200274112169

[2] Gonzaga F., Dias J., Jehnert D. et al.: Electroanal., 2013, 25, 1955. https://doi.org/10.1002/elan.201300135

[3] Laongsri B., Boonyakong C., Tangpaisarnkul N., Cherdchu C.: Accred. Qual. Assur., 2017, 12, 194.

https://doi.org/10.1007/s00769-006-0210-0

[4] Wu Y., Koch W., Marinenko G.: J. Res. Nat. Bur. Stand., 1984, 89, 395.

[5] European Pharmacopoeia, $4^{\text {th }}$ edn. Council of Europe, Strasbourg 2002.

[6] Spitzer P., Pratt K.: J. Solid State Electrochem., 2011, 15, 69. https://doi.org/10.1007/s10008-010-1106-9

[7] Nuryatini, Sujarwo, Hindayani A.: J. Standardisasi, 2015, 18, 35. [8] Hetzer H., Durst R.: J. Res. Nat. Bur. Stand., 1977, 81A, 21.

[9] Magnusson B., Örnemark U. (Eds.): Eurachem Guide: The Fitness for Purpose of Analytical Methods - A Laboratory Guide to Method Validation and Related Topics, $2^{\text {nd }}$ edn., 2014. www.eurachem.org.

[10] Gonzalez C., Watters Jr. R.: Certificate of Analysis

SRM $^{\circledR}$ NIST 185i Potassium Hydrogen Phthalate $\mathrm{pH}$ Standard, Department of Commerce United States of America 2013. [11] Yildirim A.: Certificate of Analysis Certipure ${ }^{\circledR}$ Certified Reference Material Potassium Hydrogen Phthalate, MERCK, Germany 2015.
[12] Baucke F.: J. Electroanal. Chem., 1994, 368, 67. https://doi.org/10.1016/0022-0728(93)03024-J

[13] Mustopo Y.: Effect of Time on Thickness and Adhesivity Layer in Electroplating Process of Chrome Decorative without Basic Layer with Copper Basic Layer and Copper-Nickel., Department of Mechanical Engineering, Technical Faculty of UNS, Solo, Indonesia 2011.

[14] Hamer W., Acree S.: J. Res. Nat. Bur. Stand., 1944, 33, 87.

[15] Budiman H.: Warta Kimia Analitik., 2014, 20, 18.

[16] Bell S.: Measurement Good Practice Guide (Issue 2), National Physical Laboratory, United Kingdom 2001.

[17] Subangga B., Sutikno E., Ariseno A.: Effect of Anode Variation and time of Electroplating on Wear Rate of Grinding Ball., Department of Mechanical Engineering University of Brawijaya Malang.

[18] Hioki A., Asakai T., Maksimov I. et.al.: Metrologia, 2017, 54, 08002. https://doi.org/10.1088/0026-1394/54/1A/08002

Received: March 13, 2018/Revised: April 03, 2018 / Accepted: August 30, 2018

\section{ПРИГОТУВАННЯ ВТОРИННОГО РН-СТАНДАРТУ ДЛЯ ФТАЛАТНОГО БУФЕРНОГО РОЗЧИНУ З ВИКОРИСТАННЯМ ДИФЕРЕНЦІАЛЬНОЇ ПОТЕНЦІОМЕТРИЧНОЇ КОМІРКИ: ВАЛІДАЦІЯ МЕТОДУ ТА ЗАСТОСУВАННЯ}

\begin{abstract}
Анотація. Методом диференційної потенціометрї із застосуванням електрохімічної комірки Бауке, розділеної посередині пористою скляною дисковою перегородкою на так звані дві напівкомірки, приготований фталатний буферний розчин як вторинний стандарт для величини рН. Правильність цъого методу перевірена за температури 298 К з метою оцінки його придатності. Параметри валідаиї методу включають точність (відхилення від істинного значення), прецизійність (повторюваність) та оцінку невизначеності вимірювань. Виявлено, щзо і точність, і прецизійність методу були на належсному рівні, щзо підтверджується дуже низькими величинали стандартних відхилень. Проведено очінку величини невизначеності вимірювання иього методу. Застосування валідованого аналітичного методу для вимірювання величини pH фталатного буферного розчину згідно міжнародного порівняльного випробування (АРMP.QM-K91) показало, щчо результат був близьким до паспортної (сертифікованої) величини, яка використовується як референтна для порівняння в рамках випробування АРMP.QM-K91.
\end{abstract}

Ключові слова: диференціальна потенціометрична комірка, pH, фталатний буферний розчин, валідація методу, порівняння з міжнародною референтною величиною. 